\title{
RPA2 Gene
}

National Cancer Institute

\section{Source}

National Cancer Institute. RPA2 Gene. NCI Thesaurus. Code C116634.

This gene is involved in DNA repair, recombination and replication. 